\title{
Реалізація інноваційних підходів навчання у вищий школі України засобами інформаційно-комунікаційних технологій
}

\author{
Е. В. Боєва \\ ЗВО «Південноукраїнський національний педагогічний університет імені К.Д.Ушинського»,Одеса, Україна \\ Corresponding author E-mail: taniakrupenev@gmail.com
}

Paper received 25.04.18; Accepted for publication 30.04.18.

\section{http://doi.org/10.31174/SEND-PP2018-163VI67-04}

Анотація. У статті йдеться про застосування комп'ютерних технологій у системі сучасної освіти. Доведено, що дистанційні технології дозволяють розширити можливості очної освіти, збільшивши взаємну доступність віддалених студентів, викладачів, спеціалістів, а також інформаційних масивів і, що особливо специфічно, - віртуальних освітніх об'єктів. Дистанційна освіта - це практика, яка поєднує викладача, студента, а також джерела, розміщені в різних географічних регіонах, за допомогою спеціальної технології, що дозволяє здійснювати взаємодію. 3'ясовано, що поява дистанційної освіти не є випадковою, це закономірний етап розвитку та адаптації освіти до сучасності, що $є$ перспективним засобом отримання знань різними категоріями студентів. Досвід сучасного дистанційного навчання показує його величезні переваги, адже основною ціллю віртуальної освіти, як і освіти взагалі, $\epsilon$ виявлення та досягнення людиною свого призначення у реальному світі, який поєднується з його віртуальними та іншими можливостями. Встановлено, що з появою дистанційної освіти теоретична педагогіка та освітня практика збагатилися новими поняттями та термінологією. Поєднання новітніх інформаційних технологій, сучасного програмного забезпечення та участь викладача $€$ запорукою здобуття якісної вищої освіти. З'ясовано, що використання комп'ютерних технологій у дистанційному навчанні підвищує комп'ютерну грамотність працівників освіти, сприяє збільшенню кількості користувачів глобальної мережі Інтернет та використанню їі інформаційних ресурсів для навчання, що є безумовно позитивним моментом у розвитку України.

Ключові слова: дистаниійна освіта, віртуальний клас, освітній процес, електронні видання, комп 'ютерні навчальні системи.

Доведено, що дистанційні технології дозволяють розширити можливості очної освіти, збільшивши взаємну доступність віддалених студентів, спеціалістів, а також інформаційних масивів i, що особливо специфічно, віртуальних освітніх об'єктів. Основна ж ціль віртуальної освіти, як і освіти взагалі, - це виявлення та досягнення людиною свого призначення у реальному світі, який поєднується з його віртуальними та іншими можливостями. Педагогіку, яка відповідає віртуальній освіті, у значній мірі слід вважати ситуативною, оскільки особливості іiі застосування визначаються кожен раз конкретними умовами навчання і тою віртуальною освітньою ситуацією, яка існує тільки у даному просторі, у даний час, між даними суб'єктами та об'єктами освіти. Необхідність розробки ситуативної педагогіки, як і віртуальної дидактики, випливає з потреби у конкретному інструментарії для організації віртуальних освітніх процесів.

Значний внесок у вирішення проблем ком-п’ютерних технології в навчанні зробили вітчизняні та зарубіжні вчені: Г. Громов, В. Гриценко, О. Агапова, С. Пейперт, Г. Клейман, Б. Сендов, Б. Хантер. Висвітлення проблем, пов'язаних $з$ використанням сучасних інформаційних та комп'ютерних технологій у навчальному процесі, започатковано і розвинуто в фундаментальних роботах учених: Р.Вільямса, Б.Гершунського, В.Глушкова, А.Сршова, К. Макліна, Ю. Машбиці.

У даний час, значно збільшилася роль інформаційних технологій в житті людей. Сучасне суспільство включилося в загальноісторичний процес, званий інформатизацією. Цей процес включає доступність будь-якого громадянина до джерел інформації, проникнення інформаційних технологій в наукові, виробничі, суспільні сфери, високий рівень інформаційного обслуговування. Процеси, що відбуваються у зв'язку з інформатизацією суспільства, сприяють не тільки прискоренню науковотехнічного прогресу, інтелектуалізації всіх видів людської діяльності, а й створенню якісно нового інформаційного середовища соціуму, що забезпечує розвиток творчого та професіонального потенціалу людини [2: 546].
На сучасному етапі в багатьох навчальних закладах розробляються і використовуються як окремі програмні продукти навчального призначення, так і автоматизовані навчальні системи (АНС) 3 різних навчальних дисциплін. АНС включають в себе комплекс навчальнометодичних матеріалів, комп'ютерні програми, які керують процесом навчання [1: 15].

Як зазначає Р.Гуревич, сучасні інформаційнокомунікаційні технології забезпечують доступ до високоякісних баз даних, розширюють можливість учнів і студентів у сприйманні складної інформації. Автор підкреслює, що шляхами здійснення інформатизації освіти $\epsilon$ побудова індивідуальних модульних навчальних програм різних рівнів складності залежно від конкретних потреб, використання можливостей Інтернету, упровадження дистанційного навчання, створення електронних підручників [3: 61].

Досвід сучасного дистанційного навчання показує його величезні переваги:

1. Не дивлячись на велику відстань між викладачами та студентами, спілкування між ними відбувається живо та оперативно, у дохідливій та привабливій формі.

2. Процес навчання став цікавим для студентів; приваблива сила комп'ютера примушує їх забувати про труднощі запитань; вони активно і швидко намагаються вирішити завдання, щоб швидше отримати нові.

3. Можливість "засвітитися" на весь світ примушує їх критично і об'єктивно оцінювати свої знання та можливості; вони мимоволі "підтягуються", дізнаються багато нового, привчаються до сміливості та самостійності у роботі.

4. Робота окремих студентів над черговим завданням вносить пожвавлення і різноманітність у повсякденне життя; питання чергової номінації обговорюються багатьма студентами, які навіть не беруть участі безпосередньо в курсах.

5. Навчання стало комплексним і творчим. Щоб відповісти па одне найкоротше запитання, недостатньо заглянути до якого-небудь підручника. Часто готової відповіді немає ні в яких джерелах - iї доводиться ство- 
рювати самому, напружувати свій мозок.

Успіх дистанційного проекту залежить від багатьох чинників - ідеї проекту, його привабливості, продуманості, технологічності, адміністрування та багатьох інших причин.

Одна $з$ найважливіших ролей у проведенні проектів випадає навіть не на автора, а на локальних координаторів (тьюторів) - батьків студентів, вчителів, старших товаришів, які беруть на себе відповідальність за проведення проектів на місцях - в університеті, клубі, вдома та ін. Саме завдяки чіткій організації їх роботи, продуманості дій та емоційній підтримці учасники проекту досягають своїх результатів: виконують дослідження, створюють творчі роботи, вчаться працювати з комп'ютерними програмами, беруть участь у телеконференціях і chat-дискусіях, вирішують багато технічних та організаційних проблем.

Часто від вмілої роботи локального координатора залежить те, які позитивні чи негативні - емоції отримають студенти від участі в проекті. Саме від їх уважного, навіть педантичного ставлення до технічних вимог та методичних вказівок, залежить успіх студентів. Уміння показати студентам значення проекту, допомогти у раціональній організації своєї роботи і аналізі ії результатів, і головне - організувати нагородження переможців, - все це належить до обов' язків локального координатора. Ідея застосування комп'ютера в навчальному процесі виникла у межах концепції програмованого навчання. Його переваги розглядались головним чином у розширенні можливостей індивідуального навчання. Спочатку розробка навчальних систем здійснювалася у великих наукових та навчальних центрах. До теперішнього часу майже всі створені у 60-ті роки навчальні системи втратили своє практичне значення. Але вони стимулювали інтерес до комп'ютерного навчання, активізували роботу зі створення навчальних систем. Розробка ефективних навчальних систем вимагала рішення дуже і складних психолого-педагогічних проблем. Вчителі могли використовувати комп'ютери у процесі навчання тільки за допомогою програмістів, а ті, як правило, не мали достатніх знань у сфері психології та педагогіки. Так тривало до початку 70-х років, коли різко зросла кількість комп'ютерів, які випускаються, та стала знижуватися їх вартість. Все це супроводжувалося плутаниною у сумісності програмного забезпечення комп'ютерів різних систем, що також укріпило напружене ставлення до розвитку комп'ютерного навчання педагогічної власності. На початку 80 -х років настав новий етап застосування комп'ютерів у сфері освіти. Це пов'язано з появою недорогих, зручних в експлуатації персональних комп'ютерів, які змінили уявлення про комп'ютер, як про складний механізм, працювати 3 яким можуть лише вибрані.

Відмінною особливістю сучасного етапу комп'ютерного навчання $\epsilon$ підвищений інтерес до його теоретичного обгрунтування, а звідси зростання кількості досліджень психолого-педагогічних проблем навчання за допомогою комп'ютера. З'явилися нові теорії навчання, причому деякі з них спеціально орієнтовані на комп'ютер.

Організаційно будь-яка, в тому числі і комп`ютерна технологія навчання обов язково повинна містити і традиційні форми викладача і студентів [4]. Ефективність застосування комп'ютера у навчальному процесі у знач- ній мірі залежить від якості навчальних програм. При всій різноманітності способів, які застосовуються, та прийомів можна виділити два підходи до їх складання. Для одного характерна опора на наукову теорію, для іншого - на так званий здоровий глузд, тобто інтуїтивні, часто недостатньо усвідомлені уявлення про процес навчання та індивідуальний досвід, набутий розробниками у процесі викладацької роботи. Привабливо було б з'єднати ці підходи в один, який опирався б, з одного боку, на науково обгрунтовану теорію, а 3 іншого, практику навчання. Але наукові знання не є продуктом індивідуального досвіду і навіть часто суперечать йому, а тому вчителі ставляться до них з недовірою, вважаючи ризикованим будувати на них свою поведінку. Ця обставина $є$ психологічним бар'єром, який ускладнює використання результатів наукових досліджень. Відсутністю у розробників психолого-педагогічної підготовки, в основному, пояснюється недостатня ефективність навчальних програм.

Викладачеві необхідно повною мірою оволодіти принципами комп'ютерних інтерактивних технологій, щоб використовувати їх в навчальному процесі, знати принципи розробки та використання електронних дидактичних матеріалів. Основними принципами використання електронних дидактичних матеріалів можна вважати наступні:

- наочність: ілюстрування процесу або явища дозволяє найбільш міцно закріпити отримані теоретичні знання, підвищує ефективність навчального матеріалу;

- проблемність: студенти, вирішуючи конкретні завдання, повинні на практиці застосувати знання, але й самостійно освоїти нові, тобто різноманітніше вивчати навчальний матеріал;

- індивідуальна спрямованість: матеріал підбирається 3 урахуванням досягнутого рівня студентів, диференціюючи їх складність, темп засвоєння і кількість;

- доступність: дидактичний матеріал не повинен бути як занадто складним, так і надмірно спрощеним, в іншому випадку це призводить до зниження мотивації у студентів;

- структурованість: матеріал не лише ілюструє і визначає однозначність рішення задачі, але і дозволяє виробляти варіанти оптимальних стратегій поведінки в залежності від початкових умов [5:83].

Виходячи 3 цих принципів, можна виділити наступне: демонстрація і імітація декількох варіантів залежно від початкових заданих умов; звільнення навчального часу за рахунок можливості обробки комп’ютером трудомістких і рутинних робіт з аналізу результатів навчання студентів. Слід зазначити, що деякі педагоги неоднозначно оцінюють роль комп'ютера в навчальному процесі. Відзначається їх негативний вплив на здоров'я i психіку студентів, зайва наочність призводить до зниження абстрактного мислення, захопленість до ігрового (віртуального) процесу не дає уявлення про реальність явищ та їх наслідки і т.д. Це зайвий раз підкреслює, що комп'ютерні інноваційні технології $є$ всього лише інструментом навчального процесу, головним залишається викладач, який зобов'язаний грамотно і доцільно використовувати сучасні інформаційні технології [5:84].

Звичайно, існують досить ефективні навчальні програми, створені на основі особистого досвіду розробників. Але вони швидше виняток, а не правило. Комп'ютерне навчання означає створення нових технологій, за- 
провадження яких у масовому порядку можна забезпечити, тільки вибудовуючи їх на науковій основі. Розробка теоретичних основ комп'ютерного навчання - це справа перш за все спеціалістів з педагогічних наук, у тому числі й педагогічної психології. Коли говорять про розробку теоретичних основ, мають на увазі створення або загальної психологічної теорії навчання, або спеціальної теорії комп'ютерного навчання. В останні десятиліття за кордоном з'явилося достатньо багато психологічних теорій навчання, які умовно можна розбити на три групи:

перша, яка базується на біхевіоризмі (з англ. behaviour - поведінка). Розглядає психічну діяльність людини тільки на основі реакцій поведінки на вплив зовнішнього середовища. У класичній формі ігнорується соціальна природа студента і такі поняття як свідомість, мислення та воля.

друга, яка базується на когнітивній психології. Намагається пізнати та враховувати психологічну характеристику студента.

третя, яка базується на теорії "здорового глузду" (іноді їі називають "артистичною"). Констатують інтуїтивні уявлення про навчання, які виробляються на основі особистого та колективного досвіду викладацької діяльності.

Навчання з психологічної точки зору є видом групової діяльності, який поєднує два види діяльності: власне та, що навчає (керуючу) та навчальну. Суб'єкти цих видів діяльності вирішують різні завдання: перший дидактичні (теорія освіти, навчання, виховання в процесі навчання), студенти - навчальні. Ці завдання є у певній взаємодії (навчальне завдання є компонентом навчальної діяльності), але у структурі цих видів діяльності займають не однакове місце.

Отже, механізмом навчання є управління навчальною діяльністю, а не засвоєння знань чи пізнавальна діяльність. Засвоєння знань відбувається у різноманітних видах діяльності від ігрової до виробничої. У навчальній діяльності засвоєння знань є прямим іiі продуктом, а в інших видах діяльності воно $є$ продуктом побічним. Крім цього, навчальна діяльність передбачає засвоєння не тільки знань, але й відповідних розумових дій, завдяки яким і відбувається засвоєння.

Із сказаного видно, що найточніше трактування навчання - це розгляд його як управління навчальною діяльністю, включаючи управління засвоєнням знань, пізнавальним процесом, формуванням здібностей, розвитком студентів та ін.

Економічна ефективність дистанційної підготовки забезпечується за рахунок: зведення до мінімуму кількості потрібних навчальних приміщень та витрат на обслуговування цих приміщень; використання найдешевшого та швидкодіючого виду електронного зв'язку для спілкування зі студентом; відсутності спеціальних приміщень для роботи викладачів. Віртуальний університет має необмежені можливості розвиватися у бік розширення кількості студентів, у бік збільшення кількості спеціальностей, з яких ведеться навчання і у бік збільшення кількості послуг, які надаються учням.

Перехід до інформаційного суспільства кардинально змінює положення системи освіти у суспільстві. Сучасному суспільству необхідна масова якісна освіта, спроможна забезпечити зростаючі потреби до споживача та виробника матеріальних та духовних благ. Тому поява дистанційної освіти (ДО) не випадкова, це закономірний етап розвитку та адаптації освіти до сучасних умов.

ДО - це практика, яка поєднує викладача, студента, а також джерела, розміщені в різних географічних регіонах, за допомогою спеціальної технології, що дозволяє здійснювати взаємодію. В основному, в ДО існує два підходи в забезпеченні підтримки навчання - розширення і трансформація. Модель розширення має місце тоді, коли викладач проводить урок, що технологічно мало відрізняється від традиційного, розширюючи його до інших просторових і часових рамок. Модель трансформації характеризує такі форми організації дО, які не імітують традиційну освіту, а являють собою дещо нове, специфічно пов'язане з технологіями відповідного зв'язку.

Програми ДО не обов'язково є прикладами точної відповідності тієї чи іншої моделі, проте знання відмінностей між моделями важливе для розуміння проблем психологічного і викладацького порядку, з яким зустрічається ДО. Крім того ДО привносить в теоретичну педагогіку та освітню практику нові поняття та терміни: віртуальний клас (група), підтримки освіти (підтримка студентів), учбові телекомунікаційні проекти, зворотній зв'язок, діалогова технологія, комп'ютерний зв'язок, телеконференція, координатор, модератор, фасилітатор телекомунікаційного проекту (телеконференції) та ін. Мультимедійні технології дозволяють поєднувати текст, графіку, фото, аудіо- та відео-інформацію і вносять, як зазначає Р.Гуревич, певну організацію у психічну діяльність студентів та створюють сприятливі умови для концентрації, переключення та розподілу їхньої пам'яті [3: 86].

В освітньому процесі дистанційного навчання (ДН) використовують як інноваційні так і традиційні засоби навчання: комп'ютерні навчальні системи у звичайному та мультимедійному варіантах; навчально-інформаційні аудіо та відео матеріали; лабораторні дистанційні практикуми; віртуальні мультимедійні тренажери та електронні тексти; електронні видання, електронні бібліотеки з віддаленим доступом; бази даних та бази знань з віддаленим доступом; друкарські видання. Комп'ютерні технології використовують для підвищення ефективності усіх форм навчання.

Комп'ютерні навчальні системи - комп'ютерні комплекси 3 програмними засобами навчального призначення, які дозволяють: індивідуалізувати підхід і диференціювати процес навчання; контролювати рівень засвоєння матеріалу, із діагностикою помилок та зворотнім зв'язком з першоджерелом; забезпечити самоконтроль та корекцію навчально-пізнавальної діяльності; демонструвати візуальну навчальну інформацію, моделювати та імітувати процеси і явища; проводити лабораторні роботи, експерименти і досліди в умовах віртуальної реальності; формувати досвід прийняття оптимальних рішень; підвищити інтерес до процесу навчання, використовуючи ігрові ситуації; скоротити час на трудомісткість та довготривалі обрахунки результатів практичних досліджень. Основним для успішного впровадження ДН є людський фактор. Якісне ДН можливе лише тоді, коли в даному навчальному закладі є якісне традиційне навчання. Тільки спираючись на високоякісний викладацький склад можна забезпечити зміст навчання, що відповідає світовим стандартам. Наступним за значимістю $є$ технологічний фактор. Розробка електрон- 
них видань можлива лише при наявності в навчальному закладі відповідних інформаційних технологій (пакетів програм) і досвідчених спеціалістів в галузі їх застосування.

Отже, телекомунікаційне забезпечення в системі освіти активно впливає на зміст, організацію та методи самостійної роботи тих, що навчаються. Воно розширює можливості, підвищує рівень та якість традиційного навчання. Для системи ДО наявність якісного телекому- нікаційного забезпечення $\epsilon$ найважливішою умовою стійкого функціонування системи. Крім того використання комп'ютерних технологій в ДН підвищує комп'ютерну грамотність працівників освіти, сприяє збільшенню кількості користувачів глобальної мережі Internet та використанню іiї інформаційних ресурсів для навчання, що $є$ безумовно позитивним моментом в розвитку нашої країни.

\section{ЛІТЕРАТУРА}

1. Бондаренко В.В. Современные педагогические технологи как объективная потребность [Текст] / В.В. Бондаренко, М.В. Ланских. - Харьков: ХНАДУ, 2011. - 146 с.

2. Горбунова Л.И. Использование информационных технологий в процессе обучения [Текст] / Л. И. Горбунова, Е. А. Субботина // Молодой ученый. - 2013. - №4. - С. 544-547.

3. Гуревич Р.С. Інформаційно-комунікаційні технології в навчальному процесі і посібник для педагогічних працівників, студентів педагогічних вищих навчальних закладів / Р.С. Гуревич, М.Ю. Кадемія. - Вінниця : ДОВ «Вінниця», 2002. -

$116 \mathrm{c}$.

4. Іващук К.О. Інформаційно-комунікаційні технології - як сучасний засіб в освіті [Електронний ресурс] / К.О. Іващук // Класна оцінка : освітній портал. Режим доступу : http://klasnaocinka.com.ua/ru/article/ informatsiinokomunikatsiini-tekhnologiyi--yak-suc.html.

5. Тихобаев А.Г. Интерактивные компьютерные технологии обучения / А.Г. Тихобаев // Вестник Томского государственного педагогического университета. - 2012. - № 8 (123). - C. 81-84.

\section{REFERENCES}

1. Bondarenko, V. (2011). Modern Pedagogical Techniques as an Objective Need. Kharkiv: KhNADU.

2. Gorbunova, L. (2013). Use of information technology in the educational process. Young Scientist, 4, 544-547.

3. Gurevich, R. (2002). Information and communication technologies in the educational process Vinnytsya: "Vinnytsya".

4. Ivashchuk K. Information and communication technologies as a

modern means in education // Class rating: an educational portal. Retrieved from: http://klasnaocinka.com.ua/en/article/ informatsiino-komunikatsiini-tekhnologiyi - yak-suc.html.

5. Tykhobayev, A. (2012) Interactive Computer Training Technologies. Tomsk State Pedagogical University Journal, 8 (123), 8184.

Implementation of innovative methods of training in higher school of Ukraine with use of information and communication technologies

\section{E. V. Boyeva}

Abstract. The article deals with the use of computer technologies in the system of modern education. It is proved that distance learning technologies allow expanding the possibilities of full-time education, increasing the mutual accessibility of remote students, teachers, specialists, as well as information and virtual educational facilities. Distance education is a practice that unites a teacher, a student, as well as the sources located in different geographical regions, using a special technology that allows for interaction. It is established that the emergence of distance education is not accidental, it is a natural stage of development and adaptation of education to the present and it is a promising means of acquiring knowledge by various categories of students. The experience of modern distance learning shows its huge advantages, yet, the main goal of virtual education, as well as education in general, is to identify and achieve a person's mission in the real world that is combined with his virtual and other possibilities. It is established that with the advent of distance education, theoretical pedagogy and educational practice were enriched with new concepts and terminology. The combination of the latest information technologies, modern software and the participation of the teacher is the key to obtaining a quality higher education. It is proved that the computer technologies usage in distance learning increases the computer literacy of educators, contributes to the increase in the number information resources users, is certainly a positive aspect of the development of Ukraine.

Keywords: distance education, virtual class, educational process, electronic publications, computer training systems.

Реализация инновационных методов обучения в высшей школе Украины с использованием информационнокоммуникационных технологий

Э. В. Боева

Аннотация. В статье говорится о применении компьютерных технологий в системе современного образования. Доказано, что дистанционные технологии позволяют расширить возможности очного образования, увеличив взаимную доступность отдаленных студентов, преподавателей, специалистов, а также информационных массивов и, что особенно специфично, - виртуальных образовательных объектов. Дистанционное образование - это практика, которая объединяет преподавателя, студента, а также источники, расположенные в различных географических регионах, с помощью специальной технологии, позволяющей осуществлять взаимодействие. Установлено, что появление дистанционного образования не случайно, это закономерный этап развития и адаптации образования к современности, является перспективным средством получения знаний различными категориями студентов. Опыт современного дистанционного обучения показывает его огромные преимущества, ведь основной целью виртуального образования, как и образования вообще, является выявление и достижение человеком своего назначения в реальном мире, который сочетается с его виртуальными и другими возможностями. Установлено, что с появлением дистанционного образования теоретическая педагогика и образовательная практика обогатились новыми понятиями и терминологией. Сочетание новейших информационных технологий, современного программного обеспечения и участие преподавателя является залогом получения качественного высшего образования. Доказано, что использование компьютерных технологий в дистанционном обучении повышает компьютерную грамотность работников образования, способствует увеличению количества пользователей глобальной сети Интернет и использованию ее информационных ресурсов для обучения, является безусловно положительным моментом в развитии Украины.

Ключевые слова: дистанционное образование, виртуальный класс, образовательный процесс, электронные издания, компьютерные обучающие системь. 